Anna Moszyńska

Uniwersytet Mikołaja Kopernika w Toruniu e-mail: moszynska.anna@gmail.com telefon: 566114055

DOI: $10.15290 / \mathrm{mhi} .2017 .16 .01 .09$

\title{
Rewolucja październikowa a polskie prawo spadkowe
}

\section{SUMMARY}

The October Revolution and Polish inheritance law

One of the most drastic legal solutions introduced after the outbreak of the October Revolution was the abolition of inheritance. In subsequent years the basic institutions of inheritance law have been gradually restored, but the scope of the inheritance law granted to citizens has remained narrow. The purpose of this paper is to indicate the potential impact of these Soviet patterns on contemporary Polish inheritance law. The article is divided into three parts. The first part presents a brief outline of the evolution of Soviet inheritance law, from the period of the October Revolution to 1945. Thereafter, the proposal to implement Soviet solutions into Polish law is presented. It was embodied in five theses for the project of inheritance law, prepared during the works of the Codification Commission in 1951. The last part describes the further history of this project. The article finishes with the concluding remarks in which the author seeks to indicate the legacy of the October Revolution in the current inheritance law in Poland.

Key words: October Revolution, inheritance law, codification of the civil law, Civil Law Codification Commission

Słowa kluczowe: rewolucja październikowa, prawo spadkowe, kodyfikacja prawa cywilnego, Komisja Kodyfikacji Prawa Cywilnego

1. Wkrótce po wybuchu rewolucji październikowej przeprowadzono jedną z najbardziej radykalnych reform prawnych. Dekretem z dnia 27 kwietnia 1918 r. o uchyleniu spadkobrania, zlikwidowano dziedziczenie zarówno z ustawy, jak i testamentowe ${ }^{1}$. Cały majątek, ruchomy i nieruchomy, pozostały

1 Dekret z dnia 27 (10) kwietnia 1918 r. o zniesieniu spadkobrania, Zbiór Praw i Rozporządzeń Rządu Robotniczo-Chłopskiego RSFRR, Nr 34, poz. 456. Postulat zniesienia dziedziczenia wyrazili wcześniej m.in. Marks i Engels w Manifeście Komunistycznym. K. Marks, F. Engels, Manifest Komunistyczny, [w:] K. Marks i F. Engels, Dzieła wybrane, t. 1, Warszawa 1949, s. 44. 
po śmierci właściciela, przechodził na rzecz państwa ${ }^{2}$. Pozwolono jedynie, aby majątek o niewielkiej wartości - nieprzekraczającej 10 tys. rubli - pozostawał w zarządzie małżonka i najbliższych krewnych ${ }^{3}$. Początkowo postanowienie to traktowano nie jako wyjątek od zasady zniesienia dziedziczenia, lecz jako rodzaj pomocy społecznej dla potrzebujących. Pogląd ten jednak z upływem czasu uległ zmianie i zarząd najbliższej rodziny nad spadkiem zaczęto uznawać za dziedziczenie sensu stricto ${ }^{4}$. Ponad 30 lat od wydania wspomnianego aktu, S. Szer stwierdzał, że „Rewolucja Październikowa zniosła dziedziczenie kapitalistycznej własności prywatnej, nie zniosła jednak samej instytucji spadkobrania"5. Autorzy radzieccy zaś wskazywali wręcz, że omawiany dekret postawił sobie za zadanie uchylenie własności kapitalistycznej, jednocześnie zaś stworzył podstawy socjalistycznego spadkobrania własności osobistej ${ }^{6}$.

Po tym gwałtownym i drastycznym rozwiązaniu, polegającym na zniesieniu dziedziczenia, w kolejnych latach stopniowo przywracano w Rosji Sowieckiej i ZSRR podstawowe instytucje prawa spadkowego. Dekret z 1922 r. wyraźnie wprowadzał dziedziczenie spadków - zarówno z ustawy, jak i z testamentu - do wartości 10 tys. złotych rubli przez małżonka i zstępnych spadkodawcy ${ }^{7}$. Wydany niespełna pół roku później kodeks cywilny (k.c.) utrzymał te ograniczone zasady spadkobrania ${ }^{8}$. Wprowadzono też progresywny podatek spadkowy, który początkowo wynosił do 50\%, a w kolejnych latach wzrósł aż do $90 \%$ wartości czystego spadku .

2 Por. S. Szer, Z zagadnień kodyfikacji prawa spadkowego (Uwagi ogólne), „Państwo i Prawo” (dalej: PiP) 1951, z. 5-6, s. 913. W odniesieniu do prawa spadkowego w Rosji i ZSRR zob. więcej: A. Lityński, Prawo Rosji i ZSRR 1917-1991 czyli historia wszechzwiązowego komunistycznego prawa (bolszewików). Krutki kurs, Warszawa 2012, s. 237-247.

3 Artykuł IX dekretu przewidywał, iż spadki o wartości nieprzekraczającej 10 tys. rubli, a w szczególności spadki składające się z nieruchomości rolnej, urządzenia domowego i gospodarstwa pracowniczego przechodzić będą bezpośrednio w zarząd i rozporządzenie małżonka, zstępnych i wstępnych oraz rodzeństwa spadkodawcy. Zarządzenie ludowego komisariatu sprawiedliwości doprecyzowało, iż próg 10 tys. rubli nie odnosi się do spadku obejmującego gospodarstwo pracownicze, za które uznawano gospodarstwo, w którym spadkodawca pracował sam lub co najwyżej przy pomocy żony i małoletnich dzieci. J. Gwiazdomorski, Prawo spadkowe, Warszawa 1959, s. 12.

5 S. Szer, op. cit., s. 913. Por. pogląd odmienny: N. Reich, Sozialismus und Zivilrecht. Eine rechtstheoretisch-rechtshistorische Studie zur Zivilrechtstheorie und Kodifikationspraxis im sowjetischen Gesellschaftsund Rechtssystem, Frankfurt/Main 1972, s. 92.

6 Sovetskoe graždanskoe pravo, red. M.M. Agarkov i D.M. Genkin, t. II, Moskva 1944, s. 278-280.

7 Art. 6 dekretu z dnia 2 maja 1922 r. o zasadniczych prywatnych prawach majątkowych, uznawanych w Związku Radzieckim, zabezpieczonych jego ustawami i chronionych przed sądami Związku Radzieckiego, Zbiór ustaw Rosyjskiej Socjalistycznej Republiki Rad (RSRR) Nr 36, poz. 423.

8 Art. 416-435 kodeksu cywilnego RSRR z dnia 31 października 1922 r. Dziedziczenie nadal zawężone było tylko do części majątku - powtórzono granicę 10 tys. rubli złotem. Ponadto, krąg spadkobierców ustawowych był bardzo wąski, swoboda testowania była znacznie ograniczona, nie przewidziano też instytucji zachowku. Na podstawie testamentu nie mogły dziedziczyć osoby, które nie należały do kategorii spadkobierców ustawowych.

9 Podatek ten zniesiono w 1943 r. (Dekret Prezydium Rady Najwyższej ZSRR z dnia 9 stycznia 
Przepisy prawa spadkowego zawarte $\mathrm{w}$ kodeksie cywilnym były wielokrotnie nowelizowane $\mathrm{w}$ kierunku stopniowego znoszenia wyżej wskazanych ograniczeń, m.in. w 1926 r. uchylono zawężenie przedmiotu spadku do wartości 10 tys. rubli ${ }^{10}$. W $1936 \mathrm{r}$. prawo dziedziczenia własności osobistej obywateli zostało podniesione do rangi zasady konstytucyjnej ${ }^{11}$.

Najistotniejsze zmiany do prawa spadkowego wprowadzono w $1945 \mathrm{r}^{12}$ Rozszerzono krąg dziedziców ustawowych, wprowadzając 3 grupy spadkobierców, kolejno powołanych do spadku ${ }^{13}$. W zakresie dziedziczenia testamentowego obowiązywała zasada, iż testator mógł powołać do spadku dowolną osobę tylko wówczas, gdy nie miał spadkobierców ustawowych. W przeciwnym przypadku swoboda testowania ograniczona była do wyboru jednego lub kilku spośród spadkobierców ustawowych. Bez żadnych ograniczeń można było zapisać spadek jedynie na rzecz organów państwowych lub organizacji społecznych. Przewidziano też rezerwę na rzecz małoletnich zstępnych i innych niezdolnych do pracy spadkobierców, wynoszącą cały udział spadkowy, jaki przypadałby spadkobiercy koniecznemu przy dziedziczeniu ustawowym ${ }^{14}$.

Prawo spadkowe w Rosji, a następnie w Związku Radzieckim przeszło znaczną ewolucję od okresu Wielkiej Rewolucji Październikowej, podkreślano jednak, że przebiegała ona cały czas zgodnie z założeniami marksizmu. Prawo spadkowe bowiem „od zarania rewolucji październikowej ostrzem swoim skierowane było przeciwko własności kapitalistycznej, natomiast w rozwoju swoim utrwalało coraz bardziej własność osobistą obywateli"15.

2. Czy wyżej wskazane „zdobycze” Wielkiej Socjalistycznej Rewolucji Październikowej znalazły odzwierciedlenie w polskim prawie? Wydany w $1946 \mathrm{r}$. dekret o prawie spadkowym ${ }^{16}$, pomimo przyjęcia go $\mathrm{w}$ drastycznie zmienio-

1943 r., Wiadomości Rady Najwyższej ZSRR nr 3). Podobne rozwiązanie przyjęto także w Polsce. W 1947 r. wprowadzono wysoki podatek spadkowy, którego stopa procentowa zwiększała się progresywnie - od 0,5 do 60\%, a według nowelizacji z 1949 r. nawet do $72 \%$ - w zależności od stopnia pokrewieństwa i czystej wartości spadku. Dekret z dnia 3 lutego 1947 r. o podatku od nabycia praw majątkowych (Dz. U. Nr 27, poz. 106); ustawa z dnia 2 lipca 1949 r. o zmianie dekretu z dnia 3 lutego 1947 r. o podatku od nabycia praw majątkowych (Dz. U. Nr 42, poz. 309). nr 285 - Ministerstwo Sprawiedliwości w Warszawie, teczka 2384, karta 68 (dalej: AAN 285, t. 2384, k. 68).

Art. 10 konstytucji stalinowskiej, głosił mi.in., że prawo spadkobrania osobistej własności obywateli doznaje ustawowej ochrony.

Dekret Prezydium Rady Najwyższej ZSRR z dnia 14 marca 1945 r., Wiadomości Rady Najwyższej ZSRR nr 15 i dekret Prezydium Rady Najwyższej RSFRR z dnia 12 czerwca 1945 r., Wiadomości Rady Najwyższej RSFRR nr 38.

S. Szer, op. cit., s. 916.

S. Białostocki, E. Wierzbowski, Radzieckie prawo spadkowe, „Palestra” 1959, nr 10, s. 77.

S. Szer, Tezy wstępne referatu w sprawie kodyfikacji prawa spadkowego, Archiwum Akt Nowych, zespół Dekret z dnia 8 października 1946 r. - Prawo spadkowe (Dz. U. Nr 60, poz. 328). 
nej po II światowej sytuacji politycznej, nawiązywał do zachodnioeuropejskich standardów prawnych. Czerpał bowiem głównie z obowiązujących wcześniej na ziemiach polskich ustawodawstw: BGB, kodeksu Napoleona i ABGB. Zachodnioeuropejskie kanony prawne widoczne były także w IV księdze kodeksu cywilnego uchwalonego w $1964 \mathrm{r} \cdot{ }^{17}$ Droga jednak pomiędzy tymi aktami nie była tak prosta i łatwa, jak mogłoby się to prima facie wydawać. Nie brakowało prób ukształtowania polskiego prawa spadkowego całkowicie według radzieckiego modelu. Klasyczne standardy prawa spadkowego wystawione zostały na ciężką próbę, zwłaszcza w okresie prac nad tzw. II projektem kodeksu cywilnego.

Jak powszechnie wiadomo, prowadzone w latach 1947-1948 prace nad I projektem kodeksu cywilnego zakończyły się kompletnym fiaskiem. Gotowy projekt trafił do kosza, gdyz - jak stwierdzał w słynnej samokrytyce jednej z jego głównych twórców - „wobec postępującej w gwałtownym tempie rewolucyjnej przebudowy społecznej w kierunku socjalizmu - okazało się wkrótce, że cel prac kodyfikacyjnych został określony niewłaściwie"18. Przełom polityczny, jaki nastąpił na sierpniowo-wrześniowym plenum KC PPR w 1948 r., spowodował przyspieszoną stalinizację wszystkich dziedzin życia państwowego - w tym także prawa cywilnego ${ }^{19}$.

Podjęte na nowo próby kodyfikacyjne w 1950 r. przeprowadzane były już $\mathrm{w}$ zupełnie innym duchu ${ }^{20}$. Impulsem do rozpoczęcia nowego etapu kodyfikacji był Memoriał Ministra Sprawiedliwości z 12 września 1951 r., w którym stwierdzał on, że "kodyfikacja prawa cywilnego stałaby się niewątpliwie momentem przełomowym $\mathrm{w}$ rozwoju polskiej nauki tego działu prawa, kierując ją zdecydowanie na tory marksistowskie"21.

Podstawą dla opracowania nowego projektu prawa spadkowego miały być tzw. tezy. Ich opracowanie zostało powierzone Sewerynowi Szerowi - wybitnemu cywiliście, który jednocześnie dał się poznać jako zwolennik koncepcji marksistowskich. Ówcześnie był on nie tylko sędzią Sądu Najwyższego, ale piastował także wysokie stanowisko w Ministerstwie Sprawiedliwości (wicedyrektor Departamentu Ustawodawczego).

17 Ustawa z dnia 23 kwietnia 1964 r. - Kodeks cywilny (Dz. U. Nr 16, poz. 93).

18 J. Wasilkowski, Kodyfikacja prawa cywilnego w Polsce, „Nowe Prawo” 1950, nr 12, s. 4.

19 A. Lityński, O prawie i sądach początków Polski Ludowej, Białystok 1999, s. 226; idem, Dwie wielkie transformacje prawa sądowego w Polsce XX wieku. Koncepcje i ich realizacja, [w:] W pięćsetlecie Konstytucji Nihil Novi. Z dziejów stanowienia prawa w Polsce, Warszawa 2006, s. 125; idem, Nowe ustawodawstwo $w$ nowym ustroju. O prawie karnym i cywilnym w pierwszym dwudziestoleciu Polski Ludowej, "Miscellanea Historico-Iuridica" (dalej: MHI) 2006, t. IV, s. 135.

Zob. więcej: A. Moszyńska, Prace nad kodyfikacja majątkowego prawa cywilnego w latach 1950-52. Studia dedykowane Profesorowi Adamowi Lityńskiemu w 75-lecie urodzin i 50-lecie pracy naukowej, MHI 2015, t. XIV, z. 2, s. 165-180. 
Pierwotna wersja przygotowanych przez S. Szera tez stanowiła dobitne świadectwo pełnego rozkwitu ery stalinowskiej w Polsce ${ }^{22}$. Przez pierwszych 12 stron autor przytaczał poglądy klasyków marksizmu na istotę spadkobrania, a następnie szczegółowo omawiał ewolucję radzieckiego prawa spadkowego. Z jednej strony, wywody te służyły - na szczęście - uzasadnieniu tezy, iż ${ }, \mathrm{w}$ ustroju socjalistycznym (inaczej w ustroju komunistycznym) nie ma mowy o znoszeniu instytucji spadkobrania" ${ }^{23}$. Z drugiej jednak, uzasadniać miały drastyczne zmiany $\mathrm{w}$ prawie spadkowym $\mathrm{w}$ duchu sowieckich standardów. Ostateczna wersja tez wstępnych została przedstawiona Komisji Kodyfikacyjnej na jej posiedzeniu 22 marca $1951 \mathrm{r}^{24}$

Teza pierwsza dotyczyła kręgu spadkobierców ustawowych i niemal dosłownie powtarzała ówcześnie obowiązujące rozwiązania radzieckie. Proponowano wprowadzenie trzech grup osób uprawnionych do dziedziczenia ab intestato: Do pierwszej zaliczono zstępnych spadkodawcy bez ograniczenia stopnia (na równi z nimi przysposobionego i jego zstępnych), pozostałego przy życiu małżonka oraz niezdolnych do pracy rodziców. Grupę drugą tworzyli zdolni do pracy rodzice oraz osoby niezdolne do pracy, które pozostały na utrzymaniu spadkodawcy nie krócej niż 1 rok przed jego śmiercią. $W$ ostatniej kolejności do spadku miało dochodzić rodzeństwo spadkodawcy ${ }^{25}$. Dekret Prezydium Rady Najwyższej ZSRR z 14 marca 1945 r. o spadkobiercach z ustawy i testamentu, przewidywał takie same trzy grupy spadkobierców ustawowych, z tą jedynie różnicą, iż osoby niezdolne do pracy zaliczał do I grupy.

$\mathrm{W}$ porównaniu z obowiązującym ówcześnie $\mathrm{w}$ Polsce prawem, projekt S. Szera zakładał całkowite wyłączenie od dziedziczenia zstępnych rodzeństwa. Wprowadzona natomiast miała być nowa kategoria spadkobierców osoby niezdolne do pracy pozostające na utrzymaniu spadkodawcy ${ }^{26}$. Uzasadniając proponowane zmiany S. Szer wskazywał, że w ustroju demokracji ludowej nie dadzą się utrzymać normy prawa spadkowego, jakie zabezpieczają i utrwalają niesłuszne wzbogacenie dalszych krewnych. Ich dziedziczenie bowiem stanowiło nieuzasadnione nabycie praw majątkowych bez pracy, pozostając $\mathrm{w}$ rażącej sprzeczności z zasadami współżycia społecznego. Zasadom tym

22 S. Szer, Tezy wstępne..., k. 61-80. Treść tego dokumentu została następnie - po niewielkich przeróbkach - opublikowana przez S. Szera w formie artykułu w „Państwie i Prawie” (S. Szer, Z zagadnień kodyfikacji.., s. 910-924).

23 S. Szer, Tezy wstepne..., k. 72.

24 Protokót konferencji Komisji Kodyfikacyjnej Prawa Cywilnego z dnia 22 marca 1951 r., AAN 285, t. 2384, k. 250.

25 S. Szer, Projekt Kodeksu Cywilnego. Księga czwarta. Prawo spadkowe. Tezy wstęne, AAN 285, 2384, k. 147-148.

26 Ponieważ tezy przewidywały, iż spadkobiercy wchodzący w skład tej samej grupy dziedziczyli w częściach równych, zmianie - w porównaniu z dekretem z 1946 r. - uległa też wielkość udziału przypadającego spadkobiercom. 
odpowiadało natomiast dążenie do utrwalenia stosunków rodzinnych między najbliższymi krewnymi, które uzasadniać miało dziedziczenie zstępnych, rodziców i rodzeństwa oraz współmałżonka osoby zmarłej. Wspomniane zasady współżycia uzasadniać miały także traktowanie jak krewnych osób niezdolnych do pracy, które przed śmiercią spadkodawcy pozostawały na jego wyłącznym utrzymaniu ${ }^{27}$.

Teza druga drastycznie ograniczała swobodę testowania. Spadkodawca mógł w testamencie powołać do spadku tylko osoby należące do kręgu spadkobierców ustawowych. Dziedziczyć z testamentu mogło też państwo, organizacje państwowe, spółdzielcze lub społeczne. Dopiero w braku spadkobierców ustawowych, spadkodawca mógł dowolnie ustanowić spadkobiercę testamentowego ${ }^{28}$. Stanowiła ona kalkę rozwiązań przewidzianych w Dekrecie Prezydium Rady Najwyższej ZSRR z 14 marca 1945 r. o spadkobiercach z ustawy i testamentu. Jak podkreślano $\mathrm{w}$ nauce radzieckiej, powyższe ograniczenia $\mathrm{w}$ testowaniu wynikały z konieczności godzenia osobistych interesów właściciela, $\mathrm{w}$ sensie jego prawa do rozporządzania majątkiem na wypadek śmierci, $\mathrm{z}$ interesami społecznymi, związanymi z umocnieniem rodziny radzieckiej i materialną pomocą jej członkom niezdolnym do pracy ${ }^{29}$.

Ówcześnie obowiązujące w Polsce dekret z 1946 r. nie zawierał ograniczeń swobody testowania, poza instytucją zachowku na rzecz spadkobierców koniecznych. Seweryn Szer odnosząc się do tych rozwiązań z całą mocą podkreślał, że niezbędne stało się ograniczenie prawa dziedziczenia $\mathrm{z}$ testamentu, które stanowiło samowolne i przesadne nadużywanie zasady własności prywatnej ${ }^{30}$. W jego ocenie, wola testatora zasługiwała na uwzględnienie tylko wówczas, gdy spośród osób uprawnionych do dziedziczenia ustawowego, tylko jednego lub niektórych uczynił dziedzicami, z pominięciem innych, albo gdy zmieniał ustawową kolejność, w jakiej krewni i małżonek byli powołani do spadku z ustawy.

Trzecia teza $\mathrm{w}$ istocie - choć nie używając wyraźnie tej nazwy - wprowadzała system rezerwy. Część obowiązkowa dla zstępnych małoletnich oraz pełnoletnich niezdolnych do pracy wynosić miała ich pełny ustawowy udział, czyli tyle, ile im przypadałoby, gdyby byli powołani do dziedziczenia z ustawy. W przypadku zaś pozostałych zstępnych, rodziców i małżonka, część obowiązkowa wyniosła połowę ich ustawowego udziału spadkowego ${ }^{31}$.

Było to rozwiązanie zbliżone do ówcześnie obowiązującego w Rosji Radzieckiej. Zgodnie z art. 422 kodeksu cywilnego RSFRR spadkodawca nie mógł

\footnotetext{
S. Szer, Tezy wstępne..., k. 75-76.

Idem, Projekt Kodeksu..., k. 148.

G. N. Amfiteatrov, A. P. Solodilov, Pravo nasledovaniia v SSSR, Moskva 1946, s. 27.

S. Szer, Z zagadnień kodyfikacji..., s. 921.

31 Idem, Projekt Kodeksu... Tezy wstępne, k. 148-149.
} 
pozbawić dziedziców koniecznych (tj. swoich niepełnoletnich dzieci i innych niezdolnych do pracy spadkobierców) tej części spadku, jaka im przypadałaby $\mathrm{w}$ razie dziedziczenia $\mathrm{z}$ mocy ustawy. Osoby te nie mogły więc na podstawie testamentu otrzymać mniej niż otrzymałyby w przypadku dziedziczenia ustawowego ${ }^{32}$.

Polski dekret o prawie spadkowym chronił dziedziców koniecznych w zupełnie innej formie. Przyznawał im zachowek $\mathrm{w}$ postaci roszczenia pieniężnego przeciwko spadkobiercom powołanym do spadku ${ }^{33}$. Spadkobiercy konieczni nie byli więc $\mathrm{w}$ istocie spadkobiercami ${ }^{34}$, lecz jedynie wierzycielami spadku.

Obowiązujący w polskim prawie system zachowku oparty był na rozwiązaniach kodeksu austriackiego i niemieckiego. W uzasadnieniu do swych tez, Seweryn Szer negatywnie odniósł się do tych „imperialistycznych” wzorców. Jak podkreślał, w prawie burżuazyjnym instytucja zachowku wynikała $\mathrm{z}$ tendencji do zachowania $\mathrm{w}$ całości gospodarstw rolnych i przedsiębiorstw zarobkowych. System rezerwy wiązał się bowiem z koniecznością przeprowadzenia działów spadkowych, które prowadziły do podziału majątków ziemskich, fabryk, przedsiębiorstw. Seweryn Szer uznał więc, że motywem jaki przyświecał twórcom rozwiązań o zachowku było niedopuszczenie do osłabienia - w drodze rozdrobnienia majątków - eksploatacji, stosowanej przez prywatnych właścicieli środków produkcji ${ }^{35}$.

Wobec powyższego S. Szer konstatował, że „jest rzeczą oczywistą, że zachowek, jako wyraz wspomnianej tendencji burżuazyjnego prawa, jest nie do utrzymania $\mathrm{w}$ przyszłym polskim prawie spadkowym. Jeżeli jego celem jest zabezpieczenie słusznych interesów najbliższej rodziny, jeżeli ma służyć umocnieniu tej rodziny w Państwie Ludowym (...), to jedynie słuszną jest rezerwa, oparta na zasadzie sprawiedliwego traktowania wszystkich spadkobierców" ${ }^{\prime \prime 36}$.

Teza czwarta przewidywała, że w przypadku braku uprawnionych do dziedziczenia krewnych i małżonka spadkodawcy, spadek - jako bezdziedziczny - miał przypadać Skarbowi Państwa. Również pod tym względem tezy zmierzały do zmiany zasad obowiązujących ówcześnie $\mathrm{w}$ polskim prawie. $\mathrm{W}$ świetle bowiem dekretu o prawie spadkowym, państwo (lub właściwa gmina) było ostatnim spadkobiercą ustawowym. W ocenie jednak S. Szera to rozwiązanie, czyniące ze Skarbu Państwa dziedzica z ustawy, nie było właściwe.

S. Białostocki, E. Wierzbowski, op. cit., s. 77. System rezerwy przewidywało także prawo bułgarskie (S. Szer, Z zagadnień kodyfikacji..., s. 924). kodawcy (art. 145-166). Odnośnie do kręgu spadkobierców koniecznych zob. więcej: C. Tabęcki, Osoby uprawnione do zachowku, „Demokratyczny Przegląd Prawniczy” 1948, nr 3, s. 23-25. 
Jak podkreślał, tak „cywilistyczne” ujęcie praw spadkowych było wzorowane na niektórych ustawodawstwach burżuazyjnych. Nie dało się ono utrzymać w nowym, socjalistycznym ustroju, w którym państwo jednocześnie występowało jako nosiciel władzy państwowej i prawa własności ${ }^{37}$.

Przejmowanie przez państwo majątków bezdziedzicznych, zamiast dziedziczenia ustawowego Skarbu Państwa, przewidywało nie tylko prawo radzieckie, ale także idące za jego wzorem kodeksy innych państw demoludów: Bułgarii i Czechosłowacji ${ }^{38}$.

Radzieckie prawo spadkowe opierało się także na zasadzie, że spadkobierca, który spadek przyjął, odpowiada za długi spadkowe tylko w granicach rzeczywistej wartości majątku spadkowego ${ }^{39}$. Przeszczepienie tej reguły do polskiego prawa proponował S. Szer w ostatniej - piątej tezie ${ }^{40}$. Na zupełnie odmiennym stanowisku stał polski dekret o prawie spadkowym, wskazując że spadkobierca odpowiada za długi spadkowe bez ograniczenia, chyba że przyjął spadek z dobrodziejstwem inwentarza ${ }^{41}$. Zdaniem S. Szera, ta zasada nieograniczonej odpowiedzialności $\mathrm{w}$ ustroju burżuazyjnym chroniła kredyt kapitalistyczny ${ }^{42}$, nie znajdowała natomiast uzasadnienia w warunkach gospodarki socjalistycznej. W związku z proponowanym ograniczeniem odpowiedzialności za długi, S. Szer uznał za niecelowe sporządzanie spisu inwentarza spadku. Opracowany następnie przez niego projekt prawa spadkowego znosił instytucję przyjęcia spadku z dobrodziejstwem inwentarza ${ }^{43}$. W przypadku jednak, gdy spadkobierca sporządził spis, działało domniemanie, że inwentarz ten obejmuje cały majątek spadkowy. Warto podkreślić, że ciężar dowodu, iż w spadku pozostały jeszcze inne prawa nieobjęte spisem, obciążał wierzyciela ${ }^{44}$.

Wszystkie pięć tez - bez wyjątku - wzorowanych było ściśle na prawie radzieckim. Dotykały one najważniejszych instytucji prawa spadkowego, przekształcając je według sowieckiego modelu. Zawężono istotnie kręg spadkobierców ustawowych, silnie ograniczono swobodę rozporządzania majątkiem - zarówno przez czynności inter vivos, jak i mortis causa, przyznając priorytet uprawnieniom spadkobierców koniecznych chronionych rezerwą. Spadkobranie testamentowe $\mathrm{w}$ zasadzie pozbawiono jakiegokolwiek znaczenia. Biorąc

\footnotetext{
S. Szer, Projekt Kodeksu..., k. 155; idem, Tezy wstępne..., k. 77-78.

38 S. Białostocki, E. Wierzbowski, op. cit., s. 76; S. Szer, Z zagadnień kodyfikacji..., s. 923.

39 S. Białostocki, E. Wierzbowski, op. cit., s. 69.

40 S. Szer, Projekt Kodeksu..., k. 149.

41 Art. 34-35 dekretu o prawie spadkowym z 1946 r.

42 S. Szer, Projekt Kodeksu..., k. 157.

43 Projekt kodeksu cywilnego. Księga III. Prawo spadkowe, AAN 285, t. 2384, k. 464-466.

44 Uzasadnienie szczegółowe projektowanych zmian merytorycznych obowiazującego prawa spadkowego, AAN 285, t. 2384, k. 444 i 448
} 
bowiem pod uwagę, jak bardzo zawężono krąg spadkobierców ustawowych oraz konieczność zachowania rezerwy, margines, w którym mógł się poruszać testator był tak znikomy, że trudno nazywać jego uprawnienia swobodą. Odpowiedzialność za długi spadkowe zaś proponowano ograniczyć do wysokości spadku, w sposób budzący duże zagrożenie dla wierzycieli.

3. Warto zastanowić się, z jakim odzewem wskazane wyżej wzorce radzieckie spotkały się $\mathrm{w}$ trakcie prac kodyfikacyjnych i czy ostatecznie znalazły swe odzwierciedlenie $\mathrm{w}$ kodeksie cywilnym.

Jak wyżej wskazano, tezy po raz pierwszy stały się przedmiotem dyskusji na posiedzeniu Komisji Kodyfikacyjnej w 1951 r. Wśród zgromadzonych na nim cywilistów, najwięcej kontrowersji wywołała teza pierwsza postulująca zawężenie kręgu spadkobierców ustawowych ${ }^{45}$. Wątpliwości dyskutantów jednak koncentrowały się nie wokół tej zasadniczej zmiany, lecz wokół kwestii ubocznych: zaliczenia rodziców spadkodawcy do pierwszej grupy, powołania do dziedziczenia osób utrzymywanych wcześniej przez spadkodawcę, wyłączenia od dziedziczenia krewnych spadkodawcy przez jego małżonka. Pomimo długiej debaty, nikt z dyskutantów nie zakwestionował poważnego zawężenia kręgu spadkobierców ustawowych. Zgodnie zaś przedstawionymi tezami, wyłączeni od dziedziczenia mieli być nie tylko dalsi zstępni rodzeństwa, ale nawet jego dzieci.

Jeszcze w 1951 r., projekt prawa spadkowego - w większości ucieleśniający wskazane wyżej tezy - przekazano do merytorycznego uzgodnienia wszystkim ministerstwom, urzędom centralnym i innym podmiotom ${ }^{46}$. Projekt przesłano także do prezesów sądów wojewódzkich oraz Zarządu Zrzeszenia Prawników Polskich (ZPP) w celu podjęcia nad nim dyskusji $w$ gronie specjalistów.

W trakcie tak przeprowadzonych konsultacji, wielu respondentów wypowiedziało się za włączeniem przynajmniej dzieci rodzeństwa do kręgu spadkobierców ustawowych ${ }^{47}$. Pomimo tych postulatów, opublikowany w 1954 r. projekt kodeksu cywilnego wyłączał jednak wszystkich zstępnych rodzeństwa od dziedziczenia ustawowego, a tym samym testamentowego ${ }^{48}$. Projekt ten został poddany szerokiej, publicznej dyskusji, której kulminacyjnym punktem była trzydniowa sesja naukowa zorganizowana przez Ministerstwo Sprawiedliwości i Komitet Nauk Prawnych PAN. Sesja odbywała się od 8 do 10 grudnia 1954 r.,

45 Protokót konferencji Komisji Kodyfikacyjnej Prawa Cywilnego z dnia 22 marca 1951 r., AAN 285, t. 2384, k. 250-256.

46 Sprawozdanie za czas do dnia 8 czerwca br. o pracach nad kodyfikacja prawa cywilnego i zaplanowanie wykonania dalszych prac w tym zakresie, AAN 285, t. 5633, k. 93.

47 Uwagi zgłoszone do projektu prawa spadkowego, AAN 285, t. 2187, k. 85-86.

48 Projekt Kodeksu Cywilnego Polskiej Rzeczypospolitej Ludowej, Warszawa 1954 (art. 765 i 788). 
gromadząc najwybitniejszych przedstawicieli teorii i praktyki ${ }^{49}$. W trakcie sesji referaty wygłosili dwaj główni autorzy dekretu z 1946 r. o prawie spadkowym - J. Gwiazdomorski i K. Przybyłowski. Pierwszy z nich, przedstawił uwagi dotyczące dziedziczenia ustawowego w projekcie kodeksu cywilnego ${ }^{50}$. Drugi zaś skupił się na swobodzie testowania i innych zagadnieniach spadkobrania testamentowego $\mathrm{w}$ świetle projektu ${ }^{51}$.

W swym referacie J. Gwiazdomorski na pierwszy plan wysunął zagadnienie dziedziczenia zstępnych rodzeństwa. Postulatowi przywrócenia ich do kręgu spadkobierców ustawowych poświęcił wnikliwe uwagi i obszerną argumentację ${ }^{52}$. Z całą mocą zwalczał założenie przyjęte $\mathrm{w}$ uzasadnieniu projektu, iż dzieci brata lub siostry nie są zazwyczaj dla spadkodawcy osobami bliskimi ${ }^{53}$. Jan Gwiazdomorski przypomniał, że dzieci rodzeństwa dochodzą do spadku tylko wtedy, gdy spadkodawca nie miał własnych zstępnych. Jak argumentował „dla człowieka nie mającego własnych dzieci ani wnuków, dzieci jego rodzeństwa są nie tylko najbliższymi krewnymi, ale najczęściej także osobami rzeczywiście bardzo bliskimi, a uczucie, jakim np. bezdzietny wuj czy bezdzietna ciotka obdarza swych siostrzeńców lub siostrzenice, może być bardzo silne, niekiedy mało co słabsze od uczucia, jakie rodzice żywią dla swych dzieci." ${ }^{54}$ Uczucia te Jan Gwiazdomorski doskonale znał z autopsji. Małżeństwo Jana Gwiazdomorskiego było bowiem bezdzietne, co spowodowało, że był on bardzo przywiązany do dzieci swych sióstr ${ }^{55}$.

Wypowiedź referenta spotkała się jednak z ostrą reakcją J. Wasilkowskiego - głównego redaktora projektu kodeksu cywilnego i jednego z gospodarzy sesji. Kategorycznie sprzeciwił się on wnioskom J. Gwiazdomorskiego stwierdzając, że przedstawione przez niego argumenty mają na ogół charakter subiektywny i stanowią uogólnienie osobistych spostrzeżeńn ${ }^{56}$.

49 Przebieg obrad został opublikowany nakładem Wydawnictwa Prawniczego: Materiały dyskusyjne do Projektu Kodeksu Cywilnego Polskiej Rzeczypospolitej Ludowej. Materiaty Sesji Naukowej 8-10 grudnia 1954 r., Warszawa 1955, s. 368.

J. Gwiazdomorski, Dziedziczenie ustawowe w projekcie kodeksu cywilnego PRL, [w:] Materiały dyskusyjne..., s. 221-242.

51 K. Przybyłowski, Swoboda testowania (dziedziczenie testamentowe) według projektu kodeksu cywilnego PRL, [w:] ibidem, s. 243-257.

52 Materiały dyskusyjne..., s. 226-229.

53 Por. Projekt..., Warszawa 1954, s. 157.

54 Materiaty dyskusyjne..., s. 226.

55 Jak wspominał jego siostrzeniec - H. Szarski, z wujem łączyły go niezwykle bliskie relacje: „Starszy ode mnie tylko o 13 lat, był w czasie mego dzieciństwa ukochanym wujem, później zaś zakazał mi tytułowania go wujem i stał się nieco starszym bratem". Jan Gwiazdomorski często też pomagał swoim siostrzeńcom: „bardzo ofiarnie doradzał nam w wielu sprawach i nawet załatwiał różne nasze sprawy w urzędach, gdzie zwykle spotykał swych byłych uczniów". H. Szarski, Wspomnienia, http://szarski.info/henryk_szarski_wspomnienia.htm (21.12.2016). 
Okazało się jednak, że postulat przywrócenia do kręgu spadkobierców ustawowych zstępnych rodzeństwa był powszechnie wyrażany w trakcie dyskusji $^{57}$. Kolejna wersja projektu z 1955 r. dopuszczała do dziedziczenia ustawowego dzieci braci i sióstr, pozostawiając jednak poza tym kręgiem dalszych zstępnych ${ }^{58}$.

Po raz kolejny - i ostatni - ta ważna kwestia kręgu spadkobierców ustawowych stała się przedmiotem dyskusji na posiedzeniu nowej Komisji Kodyfikacyjnej, powołanej na fali politycznej odwilży w 1956 r. ${ }^{59}$ Jan Gwiazdomorski przedstawił wówczas wniosek o zaliczenie do kręgu spadkobierców ustawowych zstępnych rodzeństwa, wywołując ożywioną dysputę. Jak można się domyślać, wnioskowi temu sprzeciwił się stanowczo J. Wasilkowski. W tej kluczowej kwestii wypowiedział się także S. Szer. Chociaż choroba uniemożliwiła mu obecność w posiedzeniu, nadesłał on swe pisemne uwagi. Podkreślał w nich, iż aktualny projekt k.c. był wynikiem kompromisu między stanowiskiem projektu z 1954 r., który wyłączał od dziedziczenia ustawowego wszystkich zstępnych rodzeństwa, a dość powszechną krytyką tego stanowiska. Kompromis ten wydawał mu się zdrowy, skoro bowiem głównym celem socjalistycznego prawa spadkowego miało być umocnienie rodziny, to tylko w takich granicach, w jakich to jest potrzebne, można wbrew zasadzie "każdemu według pracy" zezwolić na wzbogacenie się bez tej pracy. Trudno w związku z tym było znaleźć mu argumenty dla dziedziczenia z ustawy dalszych krewnych, jakimi są, poza dziećmi, dalsi zstępni rodzeństwa. Był to jedyny głos $w$ dyskusji nawiązujący jeszcze do retoryki z czasów stalinowskich.

Ostatecznie poprawka J. Gwiazdomorskiego uzyskała większość w głosowaniu $^{60}$. W ten sposób, po wielu latach podnoszonej krytyki, udało się przywrócić krąg spadkobierców ustawowych zakreślony przez dekret z 1946 r. Paradoksem jest, że poprawka w tak podstawowej kwestii przeszła zaledwie jednym głosem i to dzięki przypadkowi. Gdyby bowiem w posiedzeniu uczestniczył S. Szer, wniosek Jana Gwiazdomorskiego nie uzyskałby wymaganej większości.

Z jeszcze większą krytyką, w trakcie prac kodyfikacyjnych, spotkał się postulat ograniczenia swobody testowania, oznaczony jako teza druga $\mathrm{w}$ propozycjach S. Szera. W trakcie poświęconego omówieniu tez posiedzenia Ko-

i trybie prac Komisji Kodyfikacyjnej z 1956 roku, [w:] O prawie i jego dziejach ksiegi dwie. Studia ofiarowane Profesorowi Adamowi Lityńskiemu w czterdziestopięciolecie pracy naukowej i siedemdziesięciolecie urodzin, red. M. Mikołajczyk i in., Białystok-Katowice 2010, ks. II, s. 473-484.

60 poświęconej I czytaniu projektu kodeksu cywilnego PRL (księga V-spadki). Obrady w dniu 12 maja 1958 r. (Posiedzenia w godzinach 10.30-12.30 i 15:30-18:30), AAN 285, t. 5412, k. 115. 
misji Kodyfikacyjnej w 1951 r. na tle tej propozycji - w istocie niweczącej podstawową zasadę prawa spadkowego - rozgorzała prawdziwa batalia pomiędzy Maurycym Grudzińskim a Janem Wasilkowskim ${ }^{61}$. Sędzia Grudziński wypowiedział się stanowczo za utrzymaniem swobody testowania, spośród wielu argumentów wskazując m.in., że projekt radzieckiego kodeksu cywilnego z 1947 r. przywracał swobodę testowania ${ }^{62}$. Argumenty J. Wasilkowskiego koncentrowały się natomiast wokół socjalistycznej zasady „każdemu według pracy", z której wywodził zakaz tworzenia form ułatwiających aprioprację bez pracy. Jedyny wyłom od tej reguły dopuszczał w stosunku do członków rodziny. To zaś co M. Grudziński uważał za „ograniczenie woli” testatora, Jan Wasilkowski uznał za wyjątkowo przyznany mu przywilej. W swych wypowiedziach J. Wasilkowski posunął się do całkowitego zaprzeczenia podstawowym, klasycznym zasadom prawa cywilnego. Jak głosił, „Okoliczność, że ktoś jest właścicielem majątku, nie stwarza prawa dysponowania tym majątkiem po śmierci." ${ }^{63}$, i dalej „Własność prywatna jest niczym bez prawa dziedziczenia. W Polsce zbyt silny jest jeszcze fetyszyzm własności prywatnej i do obowiązków naszych należy podważenie go." ${ }^{64}$ Warto zauważyć, że te skrajne poglądy wypowiedziane zostały przez głównego twórcę konstrukcji prawa własności w powojennej Polsce, konstrukcji, która obowiązywała niezmiennie przez kilkadziesiąt lat ${ }^{65}$.

Koronny argument M. Grudzińskiego, odnoszący się do projektu radzieckiego, Jan Wasilkowski zwalczał wraz z obecnym na posiedzeniu ministrem sprawiedliwości H. Świątkowskim. Jak obaj podkreślali, Polska znajduje się na odmiennym etapie rozwoju i występuje w niej innych charakter własności: „Nasza własność osobista nie jest jeszcze własnością socjalistyczną i dlatego nie można tu stosować konstrukcji systemu, gdzie jest jedna - własność socjalistyczna" 66 .

Ograniczenie swobody testowania poddano krytyce jeszcze $\mathrm{w}$ trakcie uzgodnień prowadzonych w $1951 \mathrm{r}$. Przeciwko takim zmianom wypowiedzieli się nie tylko prawnicy na zebraniach zorganizowanych przez ZPP czy przedstawiciele wymiaru sprawiedliwości ${ }^{67}$, ale przede wszystkim Prezydium Rządu. Jak wskazywano, problem ten miał ówcześnie szczególne znaczenie, w obli-

61 Protokót konferencji Komisji Kodyfikacyjnej Prawa Cywilnego z dnia 22 marca 1951 r., AAN 285, t. 2384, k. 257-261.

62 Art. 627 projektu, AAN 285, t. 2187, k. 241.

63 Protokót konferencji Komisji Kodyfikacyjnej... z dnia 22 marca 1951 r., k. 260.

64 Ibidem, k. 261.

65 Por. K. Persak, „Troskliwy opiekun i światly doradca Polski Ludowej” - poprawki Józefa Stalina do Konstytucji PRL z 22 lipca 1952 r., [w:] PRL. Trwanie i zmiana, red. D. Stola, M. Zaremba, Warszawa 2003, s. 198. 
czu faktu, iż w trakcie II wojny światowej zginęło w Polsce kilka milionów osób. Wiele osób utraciło najbliższą rodzinę i wobec tego nie posiadało spadkobierców ustawowych. Obywatele ci zostaliby pozbawieni możności pozostawienia spadku osobom wprawdzie nie związanym z nimi najbliższymi więzami rodzinnymi, jednak nieraz bardzo bliskimi uczuciowo. Okoliczności te sprawiły, że w Związku Radzieckim tuż po zakończeniu wojny światowej dopuszczono nieograniczoną swobodę testowania na rzecz jakiejkolwiek osoby fizycznej w przypadku, gdy nie było spadkobierców ustawowych ${ }^{68}$.

Pomimo tej krytyki, projekt kodeksu cywilnego opublikowany w $1954 \mathrm{r}$. nie rozszerzał znacząco granic swobody testowania. Pewne złagodzenie rygorów jedynie było związane z przyjęciem nowej, stalinowskiej konstytucji i koniecznością zróżnicowania własności osobistej. Projekt z 1954 r. przewidywał, że spadkodawca mógł powołać do całości lub części spadku jedną lub kilka osób spośród swych spadkobierców ustawowych albo spośród socjalistycznych osób prawnych. Jeżeli jednak spadkodawca powołał w testamencie do dziedziczenia inną osobę, powołanie spadkobiercy rozciągało się tylko na przedmioty stanowiące własność osobistą spadkodawcy, a do takiego rozporządzenia należało stosować przepisy o zapisach (art. 788). Rozwiązanie to zostało skrytykowane $\mathrm{w}$ trakcie publicznej dyskusji przeprowadzonej nad rozwiązaniami projektu, a zwłaszcza $w$ trakcie sesji naukowej PAN ${ }^{69}$. Jednakże z podnoszonymi wówczas argumentami walczył stanowczo S. Szer, powołując się na normy konstytucji PRL uzasadniające ograniczenie swobody testowania. Stopniowe zaś rozszerzanie swobody testowania, do jakiego dochodziło w Związku Radzieckim, nie mogło w jego ocenie znaleźć zastosowania w polskich warunkach. W ZSRR bowiem przedmiotem spadku była jedynie własność osobista, w Polsce zaś dochodziło do dziedziczenia indywidualnej własności ziemi, budynków i innych środków produkcji ${ }^{70}$.

Niestety, projekt kodeksu cywilnego z $1955 \mathrm{r}$. w odniesieniu do dziedziczenia testamentowego nie wyszedł naprzeciw oczekiwaniom doktryny i praktyki. Pomimo powtarzającej się krytyki, najważniejsze ograniczenie swobody testowania pozostało bez zmian $^{71}$. Zagadnienie to uznano za na tyle przesądzone, iż nie poddano go nawet konsultacjom politycznym w specjalnie powołanej Komisji do opracowania zagadnień projektu kodeksu cywilnego.

Dopiero po zakończeniu ponurej ery stalinowskiej mogła nastąpić reasumpcja zapadłej decyzji. Doszło do niej na posiedzeniu nowej Komisji Kodyfikacyjnej, powołanej $\mathrm{w}$ ramach odwilżowych reform. W trakcie jej obrad

68 Pismo Prezydium Rady Ministrów z dnia 22 maja 1951 r. do Ministerstwa Sprawiedliwości, AAN 285, t. 2187, k. 146.

69 Materiaty dyskusyjne..., s. 243-274.

70 Ibidem, s. 275-281.

71 Projekt..., Warszawa 1955 (art. 791). 
w 1958 r. K. Przybyłowski, zaproponował odrzucenie ograniczeń swobody testowania zawartych $\mathrm{w}$ projekcie k.c. i okrojenie zasadniczego przepisu do prostego sformułowania: „Spadkodawca może powołać do całości lub części spadku jedną lub kilka osób". Do przyjęcia tego rozwiązania przekonywał zaś tym, że ewentualne ograniczenia swobody testowania można ująć w przepisach szczególnych ${ }^{72}$. Zebrani na sesji członkowie Zespołu poparli zaproponowane rozwiązanie. Taką decyzję umożliwiły dwie okoliczności. Po pierwsze, główny redaktor projektu J. Wasilkowski, wycofał się ze swego dotychczasowego stanowiska ${ }^{73}$. Po drugie, $\mathrm{w}$ trakcie opisywanego głosowania nieobecny był S. Szer. Te dwie okoliczności pozwoliły przeważyć szalę na rzecz rozwiązania K. Przybyłowskiego, które do dziś stanowi kwintesencję nieograniczonej swobody testowania ${ }^{74}$.

Najtrwalszym z postulatów S. Szera okazała się propozycja wprowadzenia systemu rezerwy $w$ miejsce zachowku pieniężnego, ujęta $\mathrm{w}$ jego tezie trzeciej. Nie wzbudziła ona większych wątpliwości w trakcie posiedzenia Komisji Kodyfikacyjnej, która uchwaliła tezy do projektu prawa spadkowego. W protokole wręcz dobitnie podkreślono, że „Komisja jednogłośnie opowiedziała się za częścią obowiązkową w postaci rezerwy"75. Podobnie, w trakcie dyskusji nad projektem k.c. z 1951 r., tylko nieliczni sędziowie wypowiedzieli się za zachowkiem $\mathrm{w}$ formie wierzytelności, przytłaczająca większość z nich poparła natomiast system rezerwy ${ }^{76}$.

Projekt kodeksu cywilnego z 1954 r. pomimo utrzymania nazwy "zachowek" również przewidywał instytucję rezerwy spadkowej ${ }^{77}$. W trakcie dyskusji nad tym projektem zdania były podzielone: część poparła nowe rozwiązania ${ }^{78}$, część natomiast skrytykowała wprowadzenie systemu zachowku in natura79.

Kolejna redakcja projektu k.c. z 1955 r. utrzymywała system rezerwy. $\mathrm{W}$ trakcie dalszych prac kodyfikacyjnych zagadnienie zabezpieczenia dziedziców koniecznych okazało się jedną z najtrudniejszych kwestii, jakie stanęły przed Komisją Kodyfikacyjną. Wielokrotnie powracano do tego problemu

72 Protokót Sesji Zespołu Prawa Cywilnego Materialnego Komisji Kodyfikacyjnej w dniach 12-16 maja 1958 r. w Madralinie. Obrady w dniu 13 maja 1958 r. (Posiedzenia w godzinach 10.30-12.30 i 15:30-18:30), AAN 285, t. 5407, k. 57-58. osobistej nie znalazło zastosowania do drobnej gospodarki chłopskiej.

Art. 791 projektu k.c. z 1955 r. w nowej wersji z 1958 r. Jest on identyczny z do dziś obowiązującym art. 959 polskiego k.c.

Protokót konferencji Komisji Kodyfikacyjnej... z dnia 22 marca 1951 r., k. 263.

Uwagi zgłoszone do projektu..., k. 94.

Materiały dyskusyjne..., s. 254-255, 279.

Ibidem, s. 259.

Ibidem, s. 275. 
szczegółowo rozważając różnego rodzaju wątpliwości, powstające w związku z systemem rezerwy: kwestię wyrównania przysporzeń, powrotu darowizn etc. Zarówno referent, jak i koreferenci przygotowali kilka wersji projektów w tym przedmiocie ${ }^{80}$. Kilkukrotnie też złożono wniosek o powrót do systemu zachowku pieniężnego. Po raz pierwszy wnioskował o to J. Gwiazdomorski, lecz jego postulat został odrzucony przez wszystkich pozostałych dyskutantów ${ }^{81}$. Na kolejnym posiedzeniu propozycję ponowił z kolei K. Przybyłowski, tym razem jednak postulat przywrócenia zachowku przepadł tylko jednym głosem ${ }^{82}$. Paradoksalnie sam Przybyłowski był znanym zwolennikiem rezerwy, jednakże sposób uregulowania tego systemu w projekcie uznał za zbyt skomplikowany i budzący liczne wątpliwości. Dlatego też uznał, że lepszym rozwiązaniem będzie utrzymanie, po dokonaniu pewnych poprawek, rozwiązań prawa spadkowego z 1946 r. ${ }^{83}$

Dopiero pod wpływem wyników dyskusji publicznej, przeprowadzonej nad projektem k.c. z 1960 r., nastąpił ostateczny powrót do systemu zachowku pieniężnego. Okazało się, iż nawet prawnicy z terenów, na których znana była rezerwa, opowiedzieli się za instytucją zachowku ${ }^{84}$.

Najkrótszy „,żywot" przypadł w udziale postulatowi wyłączenia Skarbu Państwa z kręgu dziedziców ustawowych, przewidzianemu w czwartej tezie projektu S. Szera. Co prawda pomysł ten nie wywołał żadnych zastrzeżeń na posiedzeniu Komisji Kodyfikacyjnej85, jednak później spotkał się z krytyką w trakcie międzyresortowych uzgodnien. Najpierw rozwiązanie takie zakwestionowało Ministerstwo Spraw Zagranicznych, wskazując iż ujęcie projektu uniemożliwi zgłaszanie roszczeń do spadków po zmarłych za granicą bezdziedzicznie obywatelach polskich ${ }^{86}$. Następnie wątpliwości w tym samym zakresie

80 Zob. m.in.: J. Wasilkowski, Wnioski do tytułu IV księgi o prawie spadkowym (zachowek), AAN 285, t. 5395, k. 137-139 i 141-144; idem, Wnioski w sprawie ochrony spadkobierców koniecznych, AAN 285, t. 5395, k. 146-153 i k. 155-164; J. Gwiazdomorski, Koreferat do art. 753-771, 835-878 projektu k.c. PRL, AAN 285, t. 5395, k. 28-44 i k. 46-62; K. Przybyłowski, Uwagi do ksiegi czwartej projektu k. cywilnego PRL, teczka 5395, k. 149-155 i k. 156-161.

81 Protokót Sesji Zespołu Prawa Cywilnego Materialnego Komisji Kodyfikacyjnej w dniach 12-16 maja 1958 r. w Madralinie. Obrady w dniu 14 maja 1958 r., cz. I, (posiedzenie w godz. 10.30-12.30), AAN 285, t. 5412, k. 150.

82 Protokót Sesji Zespotu Prawa Cywilnego Materialnego Komisji Kodyfikacyjnej w dniach 10-12 czerwca 1958 r. w Nieborowie. Obrady w dniu 11 czerwca 1958 r. (posiedzenia w godz. 10.30-12.30 i 15.30-18.30), AAN 285, t. 5407, k. 183.

83 Ibidem, k. 176-177.

84 Protokót Sesji Zespołu Prawa Cywilnego Materialnego Komisji Kodyfikacyjnej w dn. 22-24 maja 1961 r., Posiedzenie w dniu 22 maja 1961 r. (popołudniowe), AAN 285, t. 5413, k. 238-253; Projekt kodeksu cywilnego Polskiej Rzeczypospolitej Ludowej, Warszawa 1961, s. 206.

86 Pismo Ministerstwa Spraw Zagranicznych $z$ dnia 28 maja 1951 r. do Ministerstwa Sprawiedliwości, AAN 285, t. 2187, k. 142. 
podniosło Ministerstwo Finansów ${ }^{87}$. Z tych przyczyn postanowiono dokonać zmiany proponowanych przepisów. Już projekt k.c. z 1951 r. przewidywał, że w ostatniej grupie powołani do dziedziczenia ustawowego byli bracia i siostry spadkodawcy, a w ich braku Skarb Państwa ${ }^{88}$.

Ostatnia propozycja S. Szera - ograniczenia odpowiedzialności za długi spadkowe tylko do wysokości wartości przyjętego spadku (piąta teza) - została zakwestionowana już na pierwszym posiedzeniu Komisji Kodyfikacyjnej, poświęconym omówieniu tez ${ }^{89}$. Podnoszono wówczas, że nie wydaje się słuszne, aby osoba otrzymująca dochody bez pracy miała nie odpowiadać za długi. Ponadto wskazywano, że w ówczesnych, polskich realiach długi spadkowe nie były długami kapitalistycznymi, lecz składały się na nie kredyty zaciągnięte w bankach państwowych, zobowiązania z tytułu kupna, wyrządzonej szkody, alimentów. Przez stworzenie zaś odpowiednich norm nie powinno się zachęcać do niepłacenia długów.

Przedstawiona wyżej zasada nie wywołała większych kontrowersji w trakcie konsultacji przeprowadzonych nad projektem k.c. z 1951 r. Większość respondentów uznała za zasadne ogólne ograniczenie odpowiedzialności za długi spadkowe ${ }^{90}$. Wyjątek stanowiła opinia Jana Gwiazdomorskiego, sporządzona na zlecenie Ministerstwa Sprawiedliwości, w której podniósł on istotne zastrzeżenia wobec proponowanej konstrukcji ${ }^{11}$.

Kolejny projekt k.c. z 1954 r. przewidywał, że spadkobierca, który przyjął spadek, odpowiada za długi spadkowe w granicach wartości spadku ${ }^{92}$. W powszechnej dyskusji przeprowadzonej nad tym projektem nieliczne osoby wypowiedziały się za przywróceniem zasady nieograniczonej odpowiedzialności za długi spadkowe ${ }^{93}$. Ponownie jednak głos zabrał Jan Gwiazdomorski, i był to głos na tyle donośny, iż tym razem spowodował zmianę proponowanych rozwiązań. Na sesji PAN gorąco apelował o przywrócenie nieograniczonej odpowiedzialności za długi spadkowe, podnosząc, iż w jego ocenie jest to rozwią-

87 Pismo Ministerstwa Finansów z dnia 21 czerwca 1951 r. do Ministerstwa Sprawiedliwości, AAN 285, t. 2187, k. 162.

88 Projekt Kodeksu Cywilnego Polski Ludowej, AAN 285, t. 2391, k. 348 (art. 781 § 3).

89 Protokót konferencji Komisji Kodyfikacyjnej... z dnia 22 marca 1951 r., k. 264-265.

90 Uwagi zgloszone do projektu..., k. 96.

91 Uwagi prof. dr. Jana Gwiazdomorskiego..., AAN 285, t. 2187, k. 205-206. Przede wszystkim dla J. Gwiazdomorskiego było niezrozumiałe, dlaczego zamknięto przed spadkobiercą możliwość przyjęcia spadku wprost i wzięcia na siebie nieograniczonej odpowiedzialności za długi spadkowe. Podkreślał także, że przesłanką ograniczonej odpowiedzialności za długi spadkowe powinno być zawsze sporządzenie inwentarza, gdyż ograniczenie tej odpowiedzialności bez sporządzenia spisu stwarzało duże niebezpieczeństwo dla wierzycieli.

92 Projekt..., Warszawa 1954 (art. 833 § 1).

93 Zob. mi.in. Prawnicy lubelscy o projekcie Kodeksu Cywilnego, AAN 285, t. 2386, k. 100-101. 
zanie najprostsze i najuczciwsze ${ }^{94}$. Co najważniejsze, jego stanowisko spotkało się z aprobatą pierwszoplanowej postaci ówczesnych prac kodyfikacyjnych J. Wasilkowskiego ${ }^{95}$.

Projekt kodeksu cywilnego w nowej redakcji z 1955 r. przywracał zasadę, że spadkobierca ponosi odpowiedzialność za długi spadkowe bez ograniczenia (art. 853). Jego odpowiedzialność mogła zostać ograniczona do wartości aktywów spadku jedynie w kilku szczególnych sytuacjach (art. 854). Ostatecznie więc powrócono do rozwiązań obowiązującego ówcześnie dekretu o prawie spadkowym ${ }^{96}$.

Warto zwrócić uwagę, że chociaż twórcy kodeksu cywilnego ostatecznie odrzucili zasadę ograniczonej odpowiedzialności za długi spadkowe, reguła ta została wprowadzona do kodeksu $\mathrm{w}$ drodze jednej $\mathrm{z}$ ostatnich noweliza$\mathrm{cji}^{97}$. Zgodnie $\mathrm{z}$ nową regulacją, jeśli spadkobierca $\mathrm{w}$ wyznaczonym terminie nie złoży żadnego oświadczenia, przyjmuje spadek z ograniczeniem odpowiedzialności za długi spadkowe do wartości ustalonego w inwentarzu stanu czynnego spadku ${ }^{98}$. W uzasadnieniu proponowanych zmian podkreślano, że dotychczasowe rozwiązanie „rozmija się z powszechnym poczuciem prawnym społeczeństwa" oraz skoro dziedziczenie jest prawem, a nie obowiązkiem, naturalne wydaje się, aby spadkobierca, wbrew swojej woli, nie musiał „dokładać” do spadku'

W konsekwencji zasada ograniczonej odpowiedzialności za długi jest jedynym rozwiązaniem, z pięciu wyżej wymienionych, które obowiązuje współcześnie. Trudno jednak dopatrywać się w przyjętej w 2015 r. konstrukcji sowieckiego rodowodu. Czy zatem z dziedzictwa Wielkiej Rewolucji Październikowej nic nie przetrwało do dzisiaj? Jak wyżej wskazano, szczegółowe rozwiązania, chociaż spotkały się z różnym odbiorem, nie zostały w konsekwencji włączone do kodeksu cywilnego. Jej spuścizna jednak trwale wpisała się w polskie prawo spadkowe w bardziej ogólnym wymiarze. Księga IV kodeksu cywilnego stworzona została z myślą o zanikającej roli spadków, ograniczonych w zasadzie

94 Oczywiście J. Gwiazdomorski uważał za konieczne wprowadzenie także ograniczonej odpowiedzialności za długi spadkowe. Niezależnie jednak od niej, niezbędne w jego ocenie było otwarcie przed spadkobiercą możliwości przyjęcia na siebie odpowiedzialności nieograniczonej. Jeśli bowiem ograniczenie odpowiedzialności nie było spadkobiercy potrzebne, unikał on wówczas konieczności przedsiębrania wszystkich formalności i środków ostrożności, które w razie ograniczonej odpowiedzialności musiały być zachowane. Materiały dyskusyjne..., s. 271-272. Ibidem, s. 260.

Por. art. 37, 38 i 42 oraz art. 48-51 dekretu o prawie spadkowym z 1946 r.

Ustawa z dnia 20 marca 2015 r. o zmianie ustawy - Kodeks cywilny oraz niektórych innych ustaw (Dz.U., poz. 539)

W aktualnym stanie prawnym - w odróżnieniu od propozycji S. Szera - konieczne jest sporządzenie spisu lub wykazu inwentarza.

Druk nr 2707 - Uzasadnienie rządowego projektu ustawy o zmianie ustawy - Kodeks cywilny, Kodeks postępowania cywilnego oraz niektórych innych ustaw. 
do przedmiotów osobistego użytku. Po przeprowadzeniu gruntownej nacjonalizacji, rozparcelowaniu majątków ziemskich w drodze reformy rolnej, wygranej „bitwie o handel”, większość obywateli została pozbawiona niemal wszystkiego, poza drobną własnością osobistą. Własność nieruchomości budynkowych zastąpiły spółdzielcze prawa do lokali mieszkalnych. $Z$ większych składników majątku dziedziczeniu podlegać miały przede wszystkim gospodarstwa rolne, a te poddano szczególnym regułom, podporządkowanym celom ówczesnej polityki rolnej ${ }^{100}$. Normy prawa spadkowego skonstruowano więc z myślą, iż majątek spadkodawcy będzie niewielki, ograniczony do przedmiotów codziennego użytku. Nie przewidziano możliwości bogacenia się społeczeństwa i rozwoju w tej drodze spadków. Odradzanie bowiem własności kapitalistycznej w nowym ustroju było wykluczone. Ta "filozofia” prawa spadkowego jest właśnie głównym, pozostałym dziedzictwem rewolucji październikowej. Jej wybuch doprowadził $w$ Rosji do zniesienia spadkobrania oraz drastycznych przeobrażeń własnościowych. Jak celnie scharakteryzował je A. Lityński „Wywłaszczono ludzi z mocą wsteczną i na przyszłość, chociaż na przyszłość prawie nic im nie zostawiono"101. Chociaż przeobrażenia gospodarcze w Polsce nie miały aż tak gwałtownego przebiegu, w konsekwencji jednak majątki obywateli zredukowano niemal wyłącznie do przedmiotów własności osobistej ${ }^{102}$. Rzutowało to na sferę prawa spadkowego i przyjęte ostatecznie w kodeksie cywilnym konstrukcje.

Współcześnie podkreśla się, że przepisy księgi IV kodeksu cywilnego nie są dostosowane do wymogów gospodarki rynkowej i nie spełniają swej roli w bogacącym się społeczeństwie. Dlatego też konieczna jest reforma prawa spadkowego polegająca na jego unowocześnieniu i uelastycznieniu ${ }^{103}$.

\section{Bibliografia}

\section{Akty prawne}

Dekret z dnia 27 (10) kwietnia 1918 r. o zniesieniu spadkobrania, Zbiór Praw i Rozporządzeń Rządu Robotniczo-Chłopskiego RSFRR, Nr 34, poz. 456.

100 Zob. więcej: A. Moszyńska, Prawo w służbie gospodarki - przepisy szczególne o dziedziczeniu gospodarstw rolnych, "Z Dziejów Prawa" 2015, t. 8, s. 127-142.

101 A. Lityński, Prawo Rosji i ZSRR..., s. 240.

102 J. Gwiazdomorski, Prawo spadkowe..., s. 24-27.

103 Zadaniem tym zajmowała się Komisja Kodyfikacyjna Prawa Cywilnego działająca w latach 2002-2015 przy Ministrze Sprawiedliwości. 
Dekret z dnia 2 maja 1922 r. o zasadniczych prywatnych prawach majątkowych, uznawanych w Związku Radzieckim, zabezpieczonych jego ustawami i chronionych przed sądami Związku Radzieckiego, Zbiór ustaw Rosyjskiej Socjalistycznej Republiki Rad (RSRR) Nr 36, poz. 423.

Dekret Prezydium Rady Najwyższej ZSRR z dnia 14 marca 1945 r., Wiadomości Rady Najwyższej ZSRR nr 15.

Dekret Prezydium Rady Najwyższej RSFRR z dnia 12 czerwca 1945 r., Wiadomości Rady Najwyższej RSFRR nr 38.

Dekret z dnia 8 października 1946 r. - Prawo spadkowe (Dz. U. Nr 60, poz. 328).

Dekret z dnia 3 lutego 1947 r. o podatku od nabycia praw majątkowych (Dz. U. Nr 27, poz. 106).

Ustawa z dnia 2 lipca 1949 r. o zmianie dekretu z dnia 3 lutego 1947 r. o podatku od nabycia praw majątkowych (Dz. U. Nr 42, poz. 309).

Ustawa z dnia 23 kwietnia 1964 r. - Kodeks cywilny (Dz. U. Nr 16, poz. 93).

Ustawa z dnia 20 marca 2015 r. o zmianie ustawy - Kodeks cywilny oraz niektórych innych ustaw (Dz.U., poz. 539).

\section{Orzecznictwo}

Orzeczenie SN z dnia 27 czerwca 1950 r., Ł.C. 549/59, PiP 1950, nr 1.

\section{Dokumenty urzędowe}

Uzasadnienie rządowego projektu ustawy o zmianie ustawy - Kodeks cywilny, Kodeks postępowania cywilnego oraz niektórych innych ustaw (druk nr 2707).

\section{Archiwalia}

Archiwum Akt Nowych, zespół nr 285 - Ministerstwo Sprawiedliwości w Warszawie, sygn. teczek: 2187, 2384, 2386, 2388, 2391, 5395, 5407, 5412, 5413, 5633.

\section{Literatura}

Amfiteatrov G. N., Solodilov A. P., Pravo nasledovaniia v SSSR, Moskva 1946.

Białostocki S., Wierzbowski E., Radzieckie prawo spadkowe, „Palestra” 1959, nr 10.

Fiedorczyk P., O powstaniu, strukturze organizacyjnej i trybie prac Komisji Kodyfikacyjnej z 1956 roku, [w:] O prawie i jego dziejach ksiegi dwie. Studia ofiarowane Profesorowi Adamowi Lityńskiemu w czterdziestopięciolecie pracy naukowej i siedemdziesięciolecie urodzin, red. M. Mikołajczyk i in., Białystok-Katowice 2010, ks. II.

Gwiazdomorski J., Dziedziczenie ustawowe w projekcie kodeksu cywilnego PRL, [w:] Materiaty dyskusyjne do Projektu Kodeksu Cywilnego Polskiej Rzeczypospolitej Ludowej. Materiały Sesji Naukowej 8-10 grudnia 1954 r., Warszawa 1955. 
Gwiazdomorski J., Prawo spadkowe, Warszawa 1959.

Lityński A., Dwie wielkie transformacje prawa sadowego w Polsce XX wieku. Koncepcje i ich realizacja, [w:] W pięćsetlecie Konstytucji Nihil Novi. Z dziejów stanowienia prawa w Polsce, Warszawa 2006.

Lityński A., Nowe ustawodawstwo w nowym ustroju. O prawie karnym i cywilnym w pierwszym dwudziestoleciu Polski Ludowej, „Miscellanea Historico-Iuridica" 2006, t. IV.

Lityński A., O prawie i sądach początków Polski Ludowej, Białystok 1999.

Lityński A., Prawo Rosji i ZSRR 1917-1991 czyli historia wszechzwiazkowego komunistycznego prawa (bolszewików). Krótki kurs, Warszawa 2012.

Marks K., Engels F., Manifest Komunistyczny, [w:] K. Marks i F. Engels, Dzieła wybrane, t. 1, Warszawa 1949.

Materiały dyskusyjne do Projektu Kodeksu Cywilnego Polskiej Rzeczypospolitej Ludowej. Materiały Sesji Naukowej 8-10 grudnia 1954 r., Warszawa 1955.

Moszyńska A., Prace nad kodyfikacja majątkowego prawa cywilnego w latach 1950-52. Studia dedykowane Profesorowi Adamowi Lityńskiemu w 75-lecie urodzin i 50-lecie pracy naukowej, „Miscellanea Historico-Iuridica” 2015, t. XIV, z. 2.

Moszyńska A., Prawo w stużbie gospodarki - przepisy szczególne o dziedziczeniu gospodarstw rolnych, „Z Dziejów Prawa” 2015, t. 8.

Persak K., "Troskliwy opiekun i światły doradca Polski Ludowej” - poprawki Józefa Stalina do Konstytucji PRL z 22 lipca 1952 r., w: PRL. Trwanie i zmiana, red. D. Stola, M. Zaremba, Warszawa 2003.

Projekt Kodeksu Cywilnego Polskiej Rzeczypospolitej Ludowej, Warszawa 1954.

Projekt Kodeksu Cywilnego Polskiej Rzeczypospolitej Ludowej, Warszawa 1955.

Projekt kodeksu cywilnego Polskiej Rzeczypospolitej Ludowej, Warszawa 1961.

Reich N., Sozialismus und Zivilrecht. Eine rechtstheoretisch-rechtshistorische Studie zur Zivilrechtstheorie und Kodifikationspraxis im sowjetischen Gesellschafts- und Rechtssystem, Frankfurt/Main 1972.

Sovetskoe graždanskoe pravo, red. M.M. Agarkov i D.M. Genkin, t. II, Moskva 1944.

Szer S., Z zagadnień kodyfikacji prawa spadkowego (Uwagi ogólne), „Państwo i Prawo” 1951, z. 5-6.

Tabęcki C., Osoby uprawnione do zachowku, „Demokratyczny Przegląd Prawniczy” 1948, nr 3.

Wasilkowski J., Kodyfikacja prawa cywilnego w Polsce, „Nowe Prawo” 1950, nr 12.

\section{Netografia}

Szarski H., Wspomnienia, http://szarski.info/henryk_szarski_wspomnienia.htm. 